\title{
The relation between the therapeutic alliance and communicative intentions in therapeutic interaction during the initial phase of adolescent therapy
}

\author{
Olga Fernández González,, ${ }^{1,2}$ J. Carola Pérez,,3 Mariane Krause, \\ ${ }^{1}$ Department of Psychiatric and Mental Health, University of Chile, Santiago; ${ }^{2}$ Millennium Institute for Depression and Personality \\ Research (MIDAP), Santiago; ${ }^{3}$ Attachment and Emotional Regulation Center, Universidad del Desarrollo, Santiago; ${ }^{4}$ Psychology \\ School, Catholic University of Chile, Santiago, Chile
}

\begin{abstract}
This study aims to examine the connection between the therapeutic alliance (TA) - from both the patient's and the therapist's perspectives - and communicative intentions during the initial phase of adolescent psychotherapy. The sample comprised the first three sessions of 19 adolescents' individual psychotherapeutic processes. Fifty therapeutic conversation segments were analyzed, representing 2043 adolescent and 3208 therapist speaking turns. The variables studied were Therapeutic Alliance, measured with the Working Alliance Inventory and Communicative Intentions (Exploring, Attuning and Resignifying), assessed by the Therapeutic Activity Coding System. A multilevel analysis was performed (HLM software). The Tasks dimension of the TA perceived by the adolescents increases the likelihood that their discourse will focus on providing and requesting information (Exploring), while also reducing the probability that they will seek to work together with the therapist to achieve mutual understanding (Attuning). The therapists' discourse shows that a strong TA in the Bonds dimension makes it more probable for

Correspondence: Olga Fernández González, Department of Psychiatric and Mental Health, University of Chile, Av. La Paz 1003, Recoleta, Santiago, Chile.

Tel.: + 56.229788601.

E-mail: olgafernandez@uchile.cl their utterances to focus on the construction of new meanings (Resignifying). Also, a stronger TA in the Goals dimension makes it more likely for their discourse to be directed toward seeking Attunement with the adolescent.
\end{abstract}

Citation: Fernández González, O., Pérez, J. C., \& Krause, M. (2019). The relation between the therapeutic alliance and communicative intentions in therapeutic interaction during the initial phase of adolescent therapy. Research in Psychotherapy: Psychopathology, Process and Outcome, 22(2), 189-198. doi: 10.4081/ ripppo.2019.356

Contributions: OFG, principal investigator (original idea, design, and data analysis and interpretation; writing of the article or critical review of the text; final approval of the version to be published); CJP, methodological advisor (data analysis and interpretation; writing of the article or critical review of the text; final approval of the version to be published); MK, research advisor (original idea and design of the study; writing of the article or critical review of the text; final approval of the version to be published).

Conflict of interest: the authors declare no potential conflict of interest.

Funding: this study was supported by the Fund for Innovation and Competitiveness (FIC) of the Chilean Ministry of Economy, Development, and Tourism, through the Millennium Science Initiative, Grant No. IS130005.

Received for publication: 5 December 2018.

Revision received: 25 April 2019.

Accepted for publication: 26 April 2019.

This work is licensed under a Creative Commons Attribution NonCommercial 4.0 License (CC BY-NC 4.0).

${ }^{\circ}$ Copyright: the Author(s), 2019

Licensee PAGEPress, Italy

Research in Psychotherapy:

Psychopathology, Process and Outcome 2019; 22:189-198

doi:10.4081/ripppo.2019.356
Key words: Adolescence; Therapeutic alliance; Verbal communication; Communicative intentions.

\section{Introduction}

Psychotherapy research has consistently revealed a positive association between the quality of the therapeutic alliance (TA) in the first sessions and therapeutic outcomes, an observation that holds true for adults as well as children and adolescents (Fernández, Pérez, \& Krause, 2016; Green, 2006; Lambert, 1992; Martin, Garske, \& Davies, 2000; Shirk, \& Karver, 2003). Nevertheless, the mechanisms through which the TA operates in the generation of change have yet to be fully understood. The vast literature on alliance has not yet established whether the alliance plays a causal, moderating, or mediating role in therapeutic change (Kazdin, 2004; 2009). However, in most psychotherapeutic modes, change is constructed through verbal therapist-patient interactions (Elliott, Slatick, \& Urman, 2001; Krause et al., 2007). It is in therapeutic dialog where a series of associations and resignifications take place which make it possible to construct new representations of the self and one's relationships with others (Valdés, Krause, \& Álamo, 2011).

Although the study of verbal communication in psychotherapy has a decade-long history, during which communication styles and/or profiles connected with theoretical approaches and outcomes have been identified (Fernández 
et al., 2012; Hill, 1978; Mergenthaler, 1996; Reyes et al., 2008; Watzke, Koch, \& Schulz, 2006), the link between the TA and patient-therapist verbal communication during the session needs further research. This association between alliance and therapeutic communication is the focus of our study, especially in adolescent psychotherapy, given that the TA in adolescents has certain particularities, such as difficulties affecting its initial establishment (Fernández, Herrera, \& Escobar, 2016; Fernández, Pérez, et al., 2016; Shirk \& Karver, 2003) due to the characteristics of this developmental stage (Fernández, Herrera, et al., 2016) (search for autonomy and self-determination, critical thinking) (Páramo, 2011), the involvement of other systems in the therapeutic relationship (family, school, justice) (Binder, Holgersen, \& HØstmark, 2008; Fernández, Herrera, et al., 2016; Páramo, 2011) and the great significance and subjective appreciation that adolescents attach to it (Binder et al., 2008; Páramo, 2011).

Through a micro-process analysis of therapeutic conversation, this study aims to examine in more depth the link between the TA and adolescent-therapist verbal interaction during the early sessions of the therapy.

Microanalytic examinations of verbal interactions help us understand how change is constructed because the participants' discourse can reveal how they act during the therapeutic work session. A number of systems for microanalyzing therapeutic conversation have been developed, like: The Counselor Verbal Response Category System (CVRCS, Hill, 1978), the Text Analysis System (TAS, Mergenthaler, 1996), and the Therapeutic Activity Coding System (TACS-1.0, Valdés, Tomicic, Pérez, \& Krause, 2010) which will be used in this study.

The TACS-1.0 is a coding system based on speech acts theory (Austin, 1962; Searle, 1969) and it has a performative notion of language. This notion states that language is not only a reflection of reality, but also a constituted part of it (Austin, 1962), in the sense that to say something is to do something (Searle, 1969). Consequently, in the TACS-1.0 the verbalizations are regarded as Communicative Actions, since they fulfill the dual purpose of conveying information (Contents) and exerting an influence on others and the reality constructed by speakers (Action) (Valdés et al., 2010, p. 122). The TACS-1.0 includes five dimensions, of which prior research has highlighted the relevance of communicative intentions (CI) for therapeutic change (Dagnino, Krause, Pérez, Valdés, \& Tomicic, 2012; Fernández et al., 2012). CI refers to what the participant is trying to achieve with his/her communication (Valdés et al., 2010, p.122), without specifying whether this effect is actually achieved.

No studies have been reported that establish the relationship between CI and the TA, either in adult or adolescent therapy. However, CI have been studied in connection with therapeutic change, specifically during Change Episodes (CE) (Krause et al., 2007). CE are fragments of sessions in which there is an intensification of the process of change. These change moments are identified through the observation of the sessions (video and transcripts), conducted by expert raters trained to apply set criteria: theoretical correspondence, verifiability, novelty, and consistency (Krause et al., 2007). In adult therapy, there is evidence that a better quality of the TA during CE(Mellado et al., 2017). During CE, patients are more likely to provide information, clarify, or direct their attention toward certain contents of the conversation (Exploring), whereas therapists tend to understand, provide feedback, and align themselves with the contents verbalized by the patients (Attuning), while also seeking to construct and consolidate new meanings together with the patients (Resignifying) (Dagnino et al., 2012; Valdés et al., 2011). In this vein, studies (Fernández et al., 2012) comparing CI in Change and Stuck Episodes - fragments of sessions in which there is a temporary halt in the patient's change process, which are identified similarly to CE - have illustrated that the fundamental difference between CE and Stuck Episodes is the type of $\mathrm{CI}$, with the predominant $\mathrm{CI}$ in CE being patients' and therapists' constructions of new meanings (Resignifying). However, in both episode types, the participants demonstrated their interest in preserving their connection with the other through Attuning-oriented verbalizations. In addition, the analysis of CI throughout the therapy revealed that, in initial stages of the therapy, Exploring was more frequently used than Resignifying, especially by clients; in contrast, in the process as a whole, Resignifying surpassed the use of Exploring in the final phases of the therapy (Dagnino et al., 2012).

In psychotherapies with adolescents, only two studies have analyzed CI in connection with change processes. Specifically, it has been reported that, in successful adolescent therapies (Krause, Fernández, \& Bräutigam, 2015), the Attuning CI are significantly more frequent in therapeutic discourse than in non-successful therapies and that the latter are more likely to display the Exploring CI, with the Attuning and Resignifying CI disappearing from the therapist's repertoire. Other authors (González, Kremer, Pérez, Ulloa, \& Morán, 2018) report that, in Rupture and Repair episodes (Krause, Altimir, \& Horvath, 2011; Safran \& Muran, 2000), it is adolescent patients who are more likely to use Attuning during the therapeutic interaction to maintain a permanent link with their therapist in both episode types.

Given that the association between the TA and CI in adolescent patients has not been explored, but considering the evidence connecting CI with change (Dagnino et al., 2012; Fernández et al., 2012; Valdés et al., 2010), it can be hypothesized that CI are linked to the TA in adolescents, especially in the quality of the therapeutic bond (Bond dimension), due to the strong affective component that adolescents see in the relationship and the association that they establish with the change that they undergo (Fernández, Herrera, et al., 2016; Páramo, 2011). Consequently, the aim of this study is to examine the connection 
between the TA - from both the patient's and the therapist's perspectives - and CI during the initial phase of adolescent psychotherapy. Given that the Attuning and Resignifying CI require a great deal of perceived trust and bond safety before deep-seated meanings and patterns can be modified (Hoffart, Borge, Sexton, Clark, \& Wampold, 2012), our hypotheses suggest that: i) higher scores in the Bond dimension of the TA will be associated with the presence of the Attuning and Resignifying CI in both participants, and ii) higher scores in the Tasks and Goals dimension of the TA will be associated with the presence of the Exploring CI in both participants.

\section{Methods}

\section{Participants and materials}

The sample comprised 19 individual psychotherapeutic processes conducted in public and private outpatient mental health centers (Santiago, Chile). To be included, therapeutic processes had to be in their initial stage. Patients had to be adolescents aged 13-19 with multiple diagnoses (listed on their medical history) who, like their parents, had agreed to participate. Participants were excluded if their main diagnosis was a neurodevelopmental disorder, mental disability, or psychosis. Fifty therapeutic conversation segments were analyzed, representing 2043 adolescent and 3208 therapist speaking turns. Seven segments were missing due to patient attrition ( 3 patients, 5 segments) and failure to attend sessions ( 2 patients, 2 segments).

The adolescent patients were 14 females and five males, with an average age of 16.05 years $(S D=1.41)$. The therapists were seven females and one male, with an average age of 33.94 years $(\mathrm{S} D=9.19)$ and 10.31 years of experience on average $(S D=10.60)$ (Table 1).

\section{Measures}

The TA was assessed with the Working Alliance Inventory (WAI) (Horvath \& Greenberg, 1989), in two versions: therapists and patients. The WAI measures three domains of the TA: i) agreement between patient and therapist on the treatment goals (labeled Goal; for example my therapist and I collaborate on setting goals for my therapy); ii) agreement between patient and therapist about the tasks needed to achieve these goals (Task, I feel that the things I do in therapy will help me to accomplish the changes that I want); and iii) quality of the patienttherapist bond (Bond, I feel that my therapist appreciates $m e$ ). The WAI is a 36-item self-report measure for which respondents use a 7 -point Likert scale $(1=$ never to $7=$

Table 1. Description of the sample.

\begin{tabular}{|c|c|c|c|c|c|c|c|}
\hline ID & Age & $\begin{array}{l}\text { Adolescents } \\
\text { Gender }\end{array}$ & Diagnosis & Theoretical approach & Age & $\begin{array}{l}\text { Therapists } \\
\text { Gender }\end{array}$ & Experience (years) \\
\hline I & 17 & $\mathrm{~F}$ & Development Crisis & Systemic/Constructivist & 29 & $\mathrm{~F}$ & 3 \\
\hline II & 17 & $\mathrm{~F}$ & Disturbance Disorders & Systemic/Constructivist & 32 & $\mathrm{~F}$ & 9 \\
\hline III & 15 & M & Disturbance Disorders & Systemic/Constructivist & 32 & $\mathrm{~F}$ & 9 \\
\hline IV & 15 & $\mathrm{~F}$ & Development Crisis & Systemic/Constructivist & 31 & $\mathrm{~F}$ & 9 \\
\hline $\mathrm{V}$ & 16 & $\mathrm{~F}$ & Depressive Disorder & Psychodynamic & 36 & $\mathrm{~F}$ & 10 \\
\hline VI & 17 & $\mathrm{~F}$ & Anxiety Disorders & Systemic/Constructivist & 31 & $\mathrm{~F}$ & 8 \\
\hline VII & 17 & $\mathrm{~F}$ & Anxiety Disorders & Systemic/Constructivist & 31 & $\mathrm{~F}$ & 9 \\
\hline VIII & 16 & $\mathrm{~F}$ & Depressive Disorder & Systemic/Constructivist & 31 & $\mathrm{~F}$ & 9 \\
\hline IX & 16 & $\mathrm{~F}$ & Adjustment Disorders & Psychodynamic & 36 & $\mathrm{~F}$ & 10 \\
\hline $\mathrm{X}$ & 16 & $\mathrm{~F}$ & Depressive Disorder & Psychodynamic & 36 & $\mathrm{~F}$ & 10 \\
\hline $\mathrm{XI}$ & 17 & $\mathrm{~F}$ & Depressive Disorder & Psychodynamic & 36 & $\mathrm{~F}$ & 10 \\
\hline XII & 15 & M & Depressive Disorder & Systemic/ Constructivist & 31 & $\mathrm{~F}$ & 8 \\
\hline XIII & 16 & $\mathrm{~F}$ & Adjustment Disorders & Psychodynamic & 36 & $\mathrm{~F}$ & 10 \\
\hline XIV & 15 & $\mathrm{~F}$ & Depressive Disorder & Systemic/Constructivist & 31 & $\mathrm{~F}$ & 8 \\
\hline $\mathrm{XV}$ & 15 & M & Disturbance Disorders & Systemic/ Constructivist & 31 & $\mathrm{~F}$ & 8 \\
\hline XVI & 16 & M & Depressive Disorder & CBT & 52 & $\mathrm{~F}$ & 18 \\
\hline XVII & 17 & $\mathrm{~F}$ & Depressive Disorder & CBT & 52 & $\mathrm{~F}$ & 18 \\
\hline XVIII & 17 & M & Adjustment Disorders & Systemic/Constructivist & 35 & M & 12 \\
\hline XIX & 15 & $\mathrm{~F}$ & Mood Disorder & Systemic/Constructivist & 16 & $\mathrm{~F}$ & 18 \\
\hline
\end{tabular}

CBT, Conductual Behavioral Treatment. 
always). Both versions of the questionnaire have been translated, adapted, and validated in Chile, with their reliability coefficients reaching 0.67-0.70 (Bond), 0.80-0.85 (Task), 0.78-0.88 (Goal), and 0.93-0.90 (overall scale) for therapist and patient respectively (Santibáñez, 2001).

CI were assessed with the TACS-1.0 (Valdés et al., 2010). The TACS-1.0 distinguishes three CI types: Exploring, Attuning, and Resignifying. Exploring includes asking for or providing new information or clarifying contents (e.g., what are you afraid of?) and focusing the dia$\log$. Attuning is aimed at achieving mutual comprehension (e.g., I need you to understand what I'm trying to explain), seeking harmony, and providing feedback about what one perceives (e.g., what you just said bothered me). Resignifying is focused on transforming and consolidating meanings (e.g., you recognized that you keep your emotions inside, but that also drives you away from others). Intercoder reliability is adequate, with Cohen's kappa $=.71$ (95\% CI, .63-.87) (Valdés et al., 2010).

\section{Procedure}

The first three sessions of each therapy were audio recorded and then transcribed verbatim. The WAI was administered immediately after each of the first three therapy sessions.

Segments from each session - the first seven minutes after the midpoint of the first three sessions of each therapy - were coded with the TACS-1.0. This episode selection strategy, which has been used in similar studies (Karver et al., 2008), aimed to sample relevant segments at the same moment of each session. Two trained raters independently coded the therapeutic conversation, differentiating each patient and therapist speaking turn, and then reached a consensus coding.

This study was certified by the Ethics Committee of the Catholic University of Chile, School of Psychology. The participants - adolescents, therapists, and parents signed informed assent and consent forms.

\section{Data analysis}

Descriptive statistics of the data were estimated. At the speaking turn level, CI were analyzed using Logistic Hierarchical Regression Analysis (HLM software, full Penalized Quasi-Likelihood estimation method) given the nested nature of the data. Each CI was transformed into a dichotomous dependent variable. For example, Exploring was coded one when it was used and coded zero when Attuning or Resignifying appeared. This dichotomization process made it possible to compare the probability of occurrence of a category (coded 1) with respect to other categories (coded 0). Patient and therapist discourse were modeled as separate dependent variables.

A three-level model was established in which Level 1 represents the speaking turns, Level 2 represents sessions where the speaking turns were located, and Level 3 rep- resents the whole therapy. Only Level 2 predictors were included, considering each of the TA dimensions. The general model used was:

$\log \left[\phi_{\mathrm{ijk}} /\left(1-\phi_{\mathrm{ijk}}\right)\right]=\gamma_{000}+\gamma_{010} *$ Bond $+\gamma_{020} *$ Goals + $\gamma_{030} *$ Tasks $+\mathrm{r}_{0 \mathrm{jk}}+\mathrm{u}_{00 \mathrm{k}}$

where each predictor reflects the relationship between the TA dimensions (Bond, Goals and Tasks) and the probability of occurrence $\left(\log \left[\phi_{\mathrm{ijk}} /\left(1-\phi_{\mathrm{ijk}}\right)\right]\right)$ of each of the CI described. Four models were estimated for each CI, Where $\gamma_{010}, \gamma_{020}$ and $\gamma_{030}$ were regression coefficients that capture the effects of each one of the TA dimensions (Bond, Goals and Tasks respectively) on a dependent variable. $\gamma_{000}$ represented the probability of CI when all the TA dimensions were in the sample mean and $\mathrm{r}_{0 \mathrm{jk}}+\mathrm{u}_{00 \mathrm{k}}$ were residuals, which represent the dependent variable variability that remained after taking predictors into consideration.

The first two related self-reported alliance with the likelihood of using a given $\mathrm{CI}$ in adolescents (Model 1) and therapists (Model 2). The third model associated the alliance as reported by the therapists with the likelihood of the adolescents using a certain CI (Model 3). The final model associated the alliance as reported by the adolescent with the likelihood of their therapists using a given CI (Model 4).

\section{Results}

The TA reported by the adolescents and the therapists did not display any statistically significant differences in any of the three initial sessions considered in this study (session $1=t(18)=0.27, \mathrm{P}=.79$; session $2=t(16)=-0.05, \mathrm{P}=.96$; session $3=t(14)=-0.44, \mathrm{P}=.67)$. The correlations between patientand therapist-reported TA are presented in Table 2.

Exploring was the most commonly used CI by patients (93\%) and therapists (90\%), with Attuning and Resignifying representing less than $6 \%$ (Table 2). Exploring was inversely correlated with the use of both Resignifying and Attuning (in both patients and therapists).

\section{The exploring communicative intentions and the therapeutic alliance}

In the adolescents, there was a significant association between perceived TA and the likelihood of using Exploring. Specifically, the stronger the alliance in the Tasks dimension of the WAI as reported by adolescents $(\beta=.13$, error .05, $\mathrm{P}<.001$; OR: $1.14,1.03-1.2795 \% \mathrm{CI}$ ), the higher the likelihood of them using Exploring (Figure 1A, cell 1). Among therapists, there was no association between the likelihood of using Exploring and their perceived TA (Table 3). Regarding the relationship between one participant's perceived TA and the other's discourse, the TA reported by the adolescents displayed a significant association with the likelihood of the therapists using Exploring. The stronger the TA in the Tasks dimension $(\beta=.08$, error $.03, \mathrm{P}<.01$; OR: $1.08 ; 1.03-1.1595 \% \mathrm{CI}$ ), the 
more likely therapists used Exploring in their discourse (column A, cell 2).

The attuning communicative intentions and the therapeutic alliance

Significant associations were found between the TA and the likelihood of using the Attuning CI in both ado- lescents and therapists (Table 4). Specifically, there was an inverse association between the adolescents' reported TA and the likelihood of using Attuning. That is, the higher the alliance in the Tasks dimension, the less likely ( $\beta=-.17$, error $.04, \mathrm{P}<.001$; OR: .84, .78-.91 95\%CI) it was for the adolescents to use Attuning (Figure 1B, cell 1).

As for the therapists, a direct association was observed between the TA in the Goals dimension and the probability

Table 2. Level -1 and level- 2 descriptive statistics.

\begin{tabular}{|c|c|c|c|c|c|c|c|c|}
\hline & $M$ & $S D$ & - & 2 & 3 & 4 & 5 & 6 \\
\hline \multicolumn{9}{|l|}{ Level -1 Variables } \\
\hline 1. Exploring-Adolescents Discourse & .93 & .25 & - & $-.86 * * *$ & $-.47 * * *$ & - & - & - \\
\hline 2. Attuning-Adolescents Discourse & .04 & .22 & - & - & -.03 & - & - & - \\
\hline 3. Resignifying Adolescents Discourse & .01 & .12 & - & - & - & - & - & - \\
\hline 4. Exploring -Therapist Discourse & .90 & .30 & - & - & - & - & $-.72 * * *$ & $-.65 * * *$ \\
\hline 5. Attuning - Therapist Discourse & .05 & .23 & - & - & - & - & - & $-.05 * *$ \\
\hline 6. Resignifying - Therapist Discourse & .05 & .21 & - & - & - & - & - & - \\
\hline Level -2 Variables & $M$ & $S D$ & $N$ & 2 & 3 & 4 & 5 & 6 \\
\hline 1. Session 1-TA-Adolescent Reported & 213.34 & 27.97 & 19 & $.61 * *$ & $.83 * *$ & .12 & $.83 * * *$ & .22 \\
\hline 2. Session $1-\mathrm{TA}-$ Therapist Reported & 211.74 & 17.45 & 19 & - & $.50 *$ & $.64 * *$ & .39 & $.57 *$ \\
\hline 3. Session 2-TA - Adolescent Reported & 219.65 & 23.71 & 17 & - & - & .12 & $.86^{* * *}$ & .10 \\
\hline 4. Session $2-\mathrm{TA}-$ Therapist. Reported & 220.00 & 15.40 & 17 & - & - & - & -.00 & .42 \\
\hline 5. Session 3-TA-Adolescent Reported & 224.13 & 24.06 & 15 & - & - & - & - & .19 \\
\hline 6. Session 3-TA-Therapist Reported & 227.00 & 13.56 & 15 & - & - & - & - & - \\
\hline
\end{tabular}

Level-1 Adolescent $N=2043$; Level-1 Therapist $N=3208$. M, mean; SD, standard deviation; TA, therapeutic alliance. ${ }^{*} \mathrm{P}<.05,{ }^{*} * \mathrm{P}<.01,{ }^{* * *} \mathrm{P}<.001$.

Table 3. Parameters of hierarchical logistic regression model for predicting probability of exploring by adolescents and their therapists according to therapeutic alliance scores.

\begin{tabular}{|c|c|c|c|c|c|c|c|c|}
\hline Model & \multicolumn{2}{|c|}{$\begin{array}{c}\text { Adolescents Discourse }{ }^{\mathrm{a}} \\
\text { (Model 1) }\end{array}$} & \multicolumn{2}{|c|}{$\begin{array}{c}\text { Therapists Discourse }{ }^{\mathrm{b}} \\
\text { (Model 2) }\end{array}$} & B C & $\begin{array}{l}\text { Adolescent Discourse } \\
\text { (Model 3) } \\
\text { Odds Ratio (95\%\%IC) }\end{array}$ & \multicolumn{2}{|c|}{$\begin{array}{c}\text { Therapist Discourse }^{\mathrm{d}} \\
\text { (Model 4) } \\
\beta \text { Odds Ratio }(95 \% \% \mathrm{IC})\end{array}$} \\
\hline \multicolumn{9}{|c|}{ Fixed Effects } \\
\hline Intercept & $2.87 * * *$ & $17.75(12.34 ; 25.55)$ & $2.49 * * *$ & $* 12.17(7.41 ; 20.01)$ & $2.90 * * *$ & * $18.20(12.53 ; 26.44)$ & $2.46^{* * *}$ & $11.72(7.21 ; 19.05)$ \\
\hline Bonds - Adolescent Report & 0.01 & $1.01(0.93 ; 1.09)$ & - & - & - & - & -0.05 & $0.95(0.89 ; 1.02)$ \\
\hline Bonds - Therapist Report & - & - & 0.06 & $1.07(0.99 ; 1.15)$ & 0.08 & $1.09(0.93 ; 1.27)$ & - & - \\
\hline Goals- Adolescent Report & -0.04 & $0.96(0.89 ; 1.04)$ & - & - & - & - & -0.02 & $0.98(0.94 ; 1.03)$ \\
\hline Goals - Therapist Report & - & - & -0.08 & $0.92(0.83 ; 1.02)$ & -.01 & $0.98(0.82 ; 1.17)$ & - & - \\
\hline Tasks - Adolescent Report & $0.13 *$ & $1.14(1.03 ; 1.27)$ & - & - & - & & $0.08 * *$ & $1.09(1.03 ; 1.15)$ \\
\hline Tasks - Therapist Report & - & - & 0.03 & $1.03(0.94 ; 1.14)$ & .01 & $1.00(0.91 ; 1.12)$ & - & - \\
\hline \multicolumn{9}{|c|}{ Random Effects } \\
\hline Level-2 Intercept & 0.47 & $48.72(21 d f)^{* * *}$ & 0.56 & $105.93(23 d f)^{* * *}$ & 0.62 & $53.95(20 d f)^{* * *}$ & 0.41 & $87.00(24 d f)^{* * *}$ \\
\hline Level-3 Intercept & 0.17 & $27.13(18 d f)$ & 0.66 & $53.52(18 d f)^{* * *}$ & 0.12 & $23.12(18 d f)$ & 0.70 & $63.88(18 d f)^{* * *}$ \\
\hline
\end{tabular}




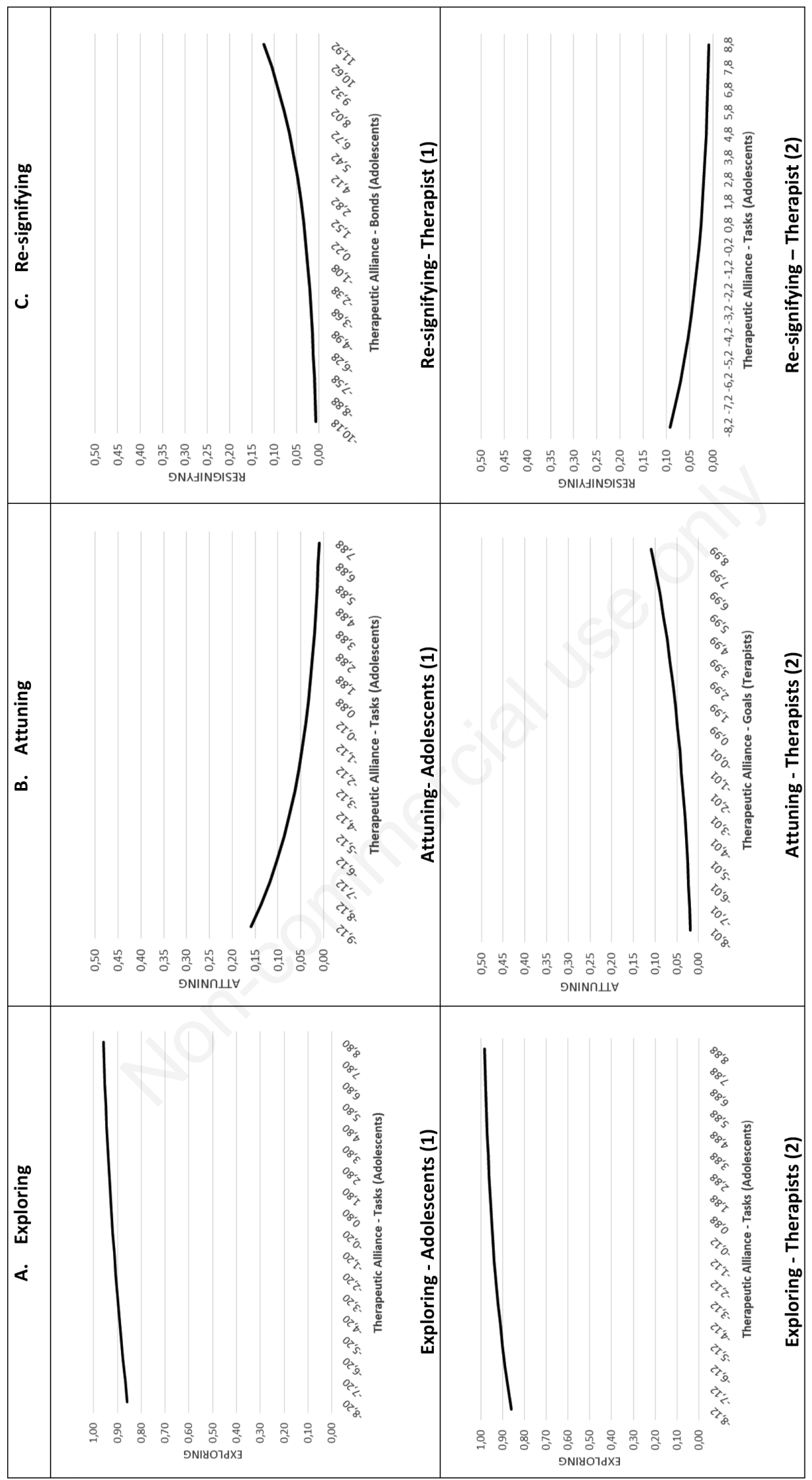

Figure 1. Probability of using communicative intentions as reported by adolescents and their therapists according to therapeutic alliance. 
of using Attuning: the stronger the alliance in the Goals dimension, the more likely $(\beta=.11$, error $.04, \mathrm{P}<.05$; OR: 1.11 , $1.01-1.2295 \% \mathrm{CI})$ the therapists were to use verbalizations aimed at Attuning during therapeutic conversation (column B, cell 2).

Regarding effects between the participants of the psychotherapeutic process, the TA as reported by the adolescents, was not found to be related to the likelihood of the therapists using Attuning and vice versa (Table 4).

\section{The resignifying communicative intentions and the therapeutic alliance}

Resignifying was observed in a very small percentage of the adolescents' speaking turns (1\%); therefore, the models were only estimated for the therapists' discourses.

Among therapists, there was a significant association only when considering the effects between the participants. Thus, the TA reported by adolescents was related to the likelihood of the therapists using Resignifying (Table 5). Specifically, the stronger the alliance in the Bonds subscale of the WAI, the more probable $(\beta=.13$, error $.02, \mathrm{P}<.001$; OR: $1.14,1.09-1.2095 \% \mathrm{CI}$ ) it was for the therapists to use Resignifying (Figure 1C, cell 1). In contrast, the stronger the alliance in the Tasks subscale, as reported by adolescents, the less likely $(\beta=-.15$, error $.04, \mathrm{P}<.001$; OR: .86 , $.79-.9395 \% \mathrm{CI}$ ) it was for the therapists to use Resignifying during verbal interaction (column $\mathrm{C}$, cell 2).

\section{Discussion}

The focus of this study was the association between the TA, measured by the WAI in its three dimensions
(Tasks, Goals, and Bond) and the CI that are present in the patients' and the therapists' speech acts. Three CI Exploring, Attuning, and Resignifying - were analyzed and linked to the three dimensions of the TA. Furthermore, in assessing the TA, we distinguished between the adolescents' and the therapists' perspectives. Therefore, our results illustrated the associations of the three dimensions of the TA with the three CI from the perspective of the two actors included in the therapeutic interaction.

Regarding the frequency of specific CI in patients' and therapists' verbalizations, the present study revealed that Exploring was the most common CI, which is in line with prior research on the predominant $\mathrm{CI}$ in the early stages of the psychotherapy (Dagnino et al., 2012). Beyond this descriptive result, an inverse association was found between the Exploring $\mathrm{CI}$ and the Attuning and Resignifying CI, which was also consistent with previous findings (Dagnino et al., 2012; Fernández et al., 2012).

Results connected to the specific focus of the present study (the association between the TA and CI) revealed a number of links between TA dimensions - bonds, tasks, and goals - and the three CI. This confirmed the importance of the TA as a multidimensional phenomenon, since its components impacted the psychotherapeutic conversation differentially.

Specifically, when the Tasks dimension of the TA was evaluated from the adolescents' perspective, it predicted the presence of the Exploring CI (seeking and providing information) both in themselves and in the therapists' verbalizations, thus confirming hypothesis ii). With the aim of further interpreting this result, it is worth asking why the Tasks dimension of the TA displays an association with the Exploring CI. A look at the WAI items that

Table 4. Parameters of hierarchical logistic regression model for predicting probability of attuning by adolescents and their therapists according to therapeutic alliance scores.

\begin{tabular}{|c|c|c|c|c|c|c|c|c|}
\hline Model & \multicolumn{2}{|c|}{$\begin{array}{c}\text { Adolescents Discourse } \\
\text { (Model 1) }\end{array}$} & \multicolumn{2}{|c|}{$\begin{array}{c}\text { Therapists Discourse } \\
\text { (Model 2) }\end{array}$} & \multicolumn{2}{|r|}{$\begin{array}{c}\text { Adolescent Discourse }^{\mathrm{c}} \\
\text { (Model 3) }\end{array}$} & \multicolumn{2}{|c|}{$\begin{array}{c}\text { Therapist Discourse } \\
\text { (Model 4) } \\
\text { / } \quad \text { Odds Ratio (95\%\%IC) }\end{array}$} \\
\hline \multicolumn{9}{|c|}{ Fixed Effects } \\
\hline Intercept & $-3.22 * * *$ & * $0.04(0.03 ; 0.06)$ & $-3.09 * * *$ & $0.05(0.03 ; 0.07)$ & $-3.20 * * *$ & * $\quad 0.05(0.03 ; 0.06)$ & $-3.06 * * *$ & $0.05(0.03 ; 0.07)$ \\
\hline Bonds - Adolescent Report & t -0.04 & $0.96(0.88 ; 1.06)$ & - & - & - & - & -0.00 & $0.99(0.93 ; 1.07)$ \\
\hline Bonds - Therapist Report & - & - & -0.04 & $0.96(0.88 ; 1.04)$ & -0.07 & $0.93(0.81 ; 1.07)$ & & \\
\hline Goals- Adolescent Report & 0.07 & $1.07(0.99 ; 1.15)$ & - & - & - & - & .00 & $1.00(0.96 ; 1.05)$ \\
\hline Goals - Therapist Report & - & - & $0.11 *$ & $1.11(1.01 ; 1.22)$ & .02 & $1.02(0.85 ; 1.21)$ & & \\
\hline Tasks - Adolescent Report & $-0.17 * * *$ & $0.84(0.78 ; 0.91)$ & - & - & - & & -.05 & $0.95(0.89 ; 1.01)$ \\
\hline Tasks- Therapist Report & - & - & -0.05 & $0.95(0.87 ; 1.04)$ & -.00 & $1.00(0.87 ; 1.16)$ & - & - \\
\hline \multicolumn{9}{|c|}{ Random Effects } \\
\hline Level-2 Intercept & 0.32 & $35.61(21 d f)^{*}$ & 0.32 & $51.86(23 d f)^{* * *}$ & 0.58 & $48.70(20 d f)^{* * *}$ & 0.34 & $56.09(26 d f)^{* * *}$ \\
\hline Level-3 Intercept & 0.25 & $30.69(18 d f)^{*}$ & 0.44 & $48.68(18 d f)^{* * *}$ & 0.15 & $21.52(18 d f)$ & 0.45 & $48.94(18 d f)^{* * *}$ \\
\hline
\end{tabular}

Dependent variable: Exploring (1) $v s$ others intentions: Resignifying and/or Attuning (0). ${ }^{a} \mathrm{~N}_{1}=2003, \mathrm{~N}_{2}=43, \mathrm{~N}_{3}=19 ;{ }^{b} \mathrm{~N}_{1}=3063, \mathrm{~N}_{2}=45, \mathrm{~N}_{3}=19 ;{ }^{c} \mathrm{~N}_{1}=1949, \mathrm{~N}_{2}=42, \mathrm{~N}_{3}=19 ;{ }^{\mathrm{d}} \mathrm{N}_{1}=3162, \mathrm{~N}_{2}=46$, $\mathrm{N}_{3}=19 . * \mathrm{P}<.05, * * \mathrm{P}<.01, * * * \mathrm{P}<.001$. 
belong to this dimension might help to interpret this result, because they emphasize the participant' tasks or duties (e.g., I clearly know what my responsibilities in the therapy are and I agree with what we are going to do in the therapy). This emphasis is consistent with the definition of the Exploring CI: requesting and providing information. Results also revealed that a better alliance in Tasks reduced the likelihood of Attuning in the adolescents' discourses, which implied that the task orientation drove them away from the focus on the more relational-emotional aspects in their communication.

As for the association between the Bond dimension of the TA and the Resignifying CI, results support hypothesis i), revealing that Resignifying becomes more frequent as the Bond dimension of the TA improves. This result is in line with the findings of Dagnino et al. (2012) and Valdés et al. (2010) in adults, demonstrating that Resignifying needs a good bond to be used by the therapists. At the communication level, this goes hand in hand with efforts devoted to Attuning. Resignifying means going a step further in the meanings offered to patients, an action that needs to be performed with the support of a strong bond between the participants.

Another specific association found is that a good TA in the Goal dimension, as reported by the therapists, increases the likelihood of Attuning. This means that the agreement on goals seems to pave the way for the therapist to focus on the more emotional aspects of communication, represented by Attuning. However, this result might be specific for psychotherapy with adolescents, and therefore needs to be further investigated and compared to adult therapy.

The importance of goals for therapists $v s$ tasks for pa- tients, in their alliance with each other, can be interpreted considering the different role of each participant in the therapeutic conversation (Dagnino et al., 2012; Valdés et al., 2011). The role of the adolescent patient, given his/her place in the life cycle, is to assert his/her self in relation to others; if he/she perceives that tasks are the key aspect of the relationship, his/her desire to Attune decreases. In contrast, the therapist has a professional role, aimed at attaining a therapeutic goal with the adolescent, which requires Attuning to generate a relationship that will enable both participants to work toward change (Resignifying). Focusing on reaching agreements regarding the duties and tasks of the therapy could steer the conversation toward practical contents and information, driving it away from the close and affectionate therapeutic relationship known to be essential for change (Fernández, Herrera, et al., 2016). Thus, the Attuning CI, in the therapist, is needed to maintain and support the relationship from the start of the therapy.

The fact that professional help has a therapeutic aim (to solve a problem) is what compels the therapist to seek affective attunement with the other; then, as the bond improves, he/she can increase his/her use of the Resignifying CI (Dagnino et al., 2012). Perceiving a secure bond enables him/her to lead the conversation toward challenging, deconstructing, and constructing new meanings (Hoffart et al., 2012).

What the present study was unable to evaluate, given the low percentage of the Resignifying CI in the adolescents' speaking turns (1\%), was whether the Bond dimension of the TA, as perceived by the therapists, increases Resignifying in the adolescents during these first sessions, which would have been a logical expectation in the initial phase of the therapy (Dagnino et al., 2012).

Table 5. Parameters of hierarchical logistic regression model for predicting probability of resignifying by adolescents and their therapists according to therapeutic alliance scores.

\begin{tabular}{|c|c|c|c|c|c|c|c|c|}
\hline Model & \multicolumn{2}{|c|}{$\begin{array}{c}\text { Adolescents Discourse } \mathrm{a}^{\mathrm{a}} \\
\text { (Model 1) }\end{array}$} & \multicolumn{2}{|c|}{$\begin{array}{c}\text { Therapists Discourse } \\
\text { (Model 2) }\end{array}$} & C) $\mathbf{B}$ & $\begin{array}{l}\text { Adolescent Discourse } \\
\text { (Model 3) } \\
\text { Odds Ratio (95\%\%IC) }\end{array}$ & \multicolumn{2}{|c|}{$\begin{array}{cc}\text { e }^{\mathrm{c}} & \text { Therapist Discourse }^{\mathrm{d}} \\
\text { (Model 4) } \\
\text { C) } \quad \beta \text { Odds Ratio (95\%\%IC) }\end{array}$} \\
\hline \multicolumn{9}{|c|}{ Fixed Effects } \\
\hline Intercept & $-4.47 * * *$ & * $0.01(0.01 ; 0.02)$ & $-3.51 * * *$ & $* 0.03(0.02 ; 0.05)$ & $-4.49 * * *$ & $* \quad 0.01(0.00 ; 0.02)$ & $-3.51 * * *$ & $0.03(0.02 ; 0.06)$ \\
\hline Bonds - Adolescent Report & - & - & - & - & - & - & $0.13 * * *$ & $1.14(1.09 ; 1.20)$ \\
\hline Bonds - Therapist Report & - & - & -0.02 & $0.98(0.86 ; 1.10)$ & - & - & - & - \\
\hline Goals- Adolescent Report & - & - & - & - & - & - & 0.04 & $1.04(0.96 ; 1.12)$ \\
\hline Goals - Therapist Report & - & - & -0.02 & $0.98(0.85 ; 1.12)$ & - & - & - & - \\
\hline Tasks - Adolescent Report & - & - & - & - & - & - & $-0.15 * * *$ & $0.86(0.79 ; 0.93)$ \\
\hline Tasks - Therapist Report & - & - & -0.00 & $0.99(0.89 ; 1.11)$ & - & - & - & - \\
\hline \multicolumn{9}{|c|}{ Random Effects } \\
\hline Level-2 Intercept & 0.77 & $24.61(24 d f)$ & 0.95 & $90.67(23 d f)^{* * *}$ & 1.05 & $23.85(23 d f)$ & 0.32 & $44.59(24 d f)^{*}$ \\
\hline Level-3 Intercept & 0.44 & $24.48(18 d f)$ & 0.70 & $39.40(18 d f)^{* *}$ & 0.20 & $19.82(18 d f)$ & 1.12 & $80.32(18 d f)^{* * *}$ \\
\hline
\end{tabular}


Another limitation derives from the fact that data were collected in specific seven-minute segments of the first three sessions of psychotherapies. With data belonging only to these segments, we are unable to address the evolution of CI during the whole session, which would be a time-consuming, but potentially worthy challenge for future studies. Additionally, given the study's focus on the first three sessions, even considering that research has provided support for their importance in establishing a good TA (Hill, 2005), we were not able to assess the further evolution of the TA during the therapeutic process or its relation to CI. Results of a study on CI in adults during the whole therapy (Dagnino et al., 2012) reveal that there is an evolution of CI throughout the process. Whether this evolution is similar in therapies with adolescents, and how it relates to the TA, are questions that can be addressed in future research.

\section{Conclusions}

Exploring is the $\mathrm{CI}$ that both therapists and patients use most frequently in the initial phase of adolescent therapy. Our analyses of the relationship between the Bonds, Tasks, and Goals subscales of the TA and CI illustrate that the Tasks dimension of the TA - as perceived by the adolescents - increases the likelihood that their discourse will focus on providing and requesting information (Exploring), while also reducing the probability that they will seek to work together with the therapist to achieve mutual understanding (Attuning). For its part, the Tasks dimension - as perceived by the adolescents - impacts on the therapist's discourse, increasing the likelihood that he/she will guide the patient toward exploring and clarifying information.

Our analysis of the therapists' discourses illustrate that a strong TA in the Bond dimension make it more probable for their utterances to focus on the construction of new meanings (Resignifying). Also, a stronger TA in the Goals dimension makes it more likely for their discourse to be directed toward seeking Attunement with the adolescent.

\section{References}

Austin, JL. (1962). How to do things with words. Oxford: Clarendon Press.

Binder, P., Holgersen, H., \& HØstmark, G. (2008). Establishing a bond that works: a qualitative study of how psychotherapists make contact with adolescent patients European Journal of Psychotherapy \& Counselling, 10(1), 55-69. doi: 10.1080/13642530701869730

Dagnino, P., Krause, M., Pérez, C., Valdés, N., \& Tomicic, A. (2012). The evolution of communicative intentions during change episodes and throughout the therapeutic process. Research in Psychotherapy: Psychopathology, Process and Outcome, 15(2), 75-86. doi: 10.4081/ripppo.2012.107

Elliott, R., Slatick, E., \& Urman, M. (2001). Qualitative change process research on psychotherapy: Alternative strategies. Psychologische Beiträge, 43(3), 69-101.
Fernández, O., Herrera, P., \& Escobar, MJ. (2016). Adolescentes en psicoterapia: su representación de la relación terapéutica [Adolescents in psychotherapy: their representation of the therapeutic relationship]. Revista Latinoamericana de Ciencias Sociales, Niñez y Juventud, 14(1), 559-575.

Fernández, O., Herrera, P., Krause, M., Vilches, O., Valdés, N., \& Dagnino, P. (2012). Episodios de cambio y estancamiento en psicoterapia: características de la comunicación verbal entre pacientes y terapeutas [Episodes of change and stagnation in psychotherapy: characteristics of verbal communication between patients and therapists]. Terapia Psicológica, 30(2), 522. doi: $10.4067 / \mathrm{S} 0718-4808201200020000$

Fernández, O., Pérez, C., \& Krause, M. (2016). Therapeutic alliance in the initial phase of psychotherapy with adolescents: different perspectives and their association with therapeutic outcomes. Research in Psychotherapy: Psychopathology, Process and Outcome, 19(1), 1-9. doi: 10.4081/ripppo. 2016.180

González, Y., Kremer, B., Pérez, H., Ulloa, I., \& Morán, J. (2018). ¿Cómo hablan los pacientes adolescentes y sus terapeutas cuando se rompe y repara la alianza terapéutica? [How do teenage patients and their therapists talk when the therapeutic alliance is broken and repaired?] In M. E. Molina (President), $15^{\circ}$ Congreso Chileno de Psicoterapia y $13^{\circ}$ Congreso Latinoamericano De Investigación En Psicoterapia. "Vulnerabilidades: Límites Y Movimiento" Society for Psychotherapy Research. Latino America Chapter. Reñaca, Chile.

Green, J. (2006). Annotation: the therapeutic alliance. A significant but neglected variable in child mental health treatment studies. Journal of Child Psychology and Psychiatric 47(5), 425-435. doi: 10.1111/j.1469-7610.2005. 01516.x

Hill, C. (1978). The development of a system for classifying counselor responses. Journal of Counseling Psychology, 25, 461-468.

Hill, C. (2005). Therapist techniques, client involvement, and the therapeutic relationship: inextricably intertwined in the therapy process. Psychotherapy: Theory, Research, Practice, Training, 42, 431-442.

Hoffart, A., Borge, F-M., Sexton, H., Clark, D. M., \& Wampold, B. (2012). Psychotherapy for social phobia: How do alliance and cognitive process interact to produce outcome? Psychotherapy Research, 22(1), 82-94. doi: 10.1080/10503307. 2011.626806

Horvath, A. O., \& Greenberg, L. S. (1989). Development and validation of the Working Alliance Inventory. Journal of Counseling Psychology, 36(2), 223-233.

Karver, M., Shirk, S., Handelsman, J. B., Fields, S., Crisp, H., Gudmundsen, G., \& McMakin, D. (2008). Relationship processes in youth psychotherapy: Measuring alliance, alliance-building behaviors, and client involvement. Journal of Emotional and Behavioral Disorders, 16(1), 15-28. doi: $10.1177 \% 2 \mathrm{~F} 1063426607312536$

Kazdin, A. (2004). Psychotherapy for children and adolescents. In W. J. Lambert (Ed.), Bergin and Garfield's handbook of psychotherapy and behavior change (5th ed., pp. 543-589). New York: Wiley and Sons.

Kazdin, A. (2009). Understanding how and why psychotherapy leads to change Psychotherapy Research, 19(4-5), 418-428. doi: 10.1080/10503300802448899

Krause, M., Altimir, C., \& Horvath, A. (2011). Deconstructing the therapeutic alliance: Reflections on the underlying dimensions of the concept. Clínica y Salud, 22(3), 267-283. 
Krause, M., De la Parra, G., Arístegui, R., Dagnino, P., Tomicic, A., Valdés, N., ... Ramírez, I. (2007). The evolution of therapeutic change studied through generic change indicators. Psychotherapy Research, 17(6), 673-689. doi: 10.1080/ 10503300601158814

Krause, M., Fernández, O. M., \& Bräutigam, B. (2015). Ergebnisqualität von psychotherapeutischen Prozessen mit Jugendlichen [Quality of the results of therapeutic processes in adolescents]. Psychotherapeut, 60(5), 419-425. doi: 10.1007/s00278-015-0037-4

Lambert, M. J. (1992). Psychotherapy outcome research: Implications for integrative and eclectical therapists. In J. C. Norcross, \& M. R. Goldfried (Eds.), Handbook of psychotherapy integration (pp. 94-129). New York: Basic Books.

Martin, D. J., Garske, J. P., \& Davis, M. K. (2000). Relation of the therapeutic alliance with outcome and other variables: a meta-analytic review. Journal of Consulting and Clinical Psychology, 68(3), 438-450. doi: 10.1037/0022-006X.68.3.438

Mellado, A., Suárez, N., Altimir, C., Martínez, C., Pérez, J. C., Krause, M., \& Horvath, A. (2017). Disentangling the changealliance relationship: Observational assessment of the therapeutic alliance during change and stuck episodes. Psychotherapy Research, 27(5), 595-607. doi: 10.1080/ 10503307.2016.1147657

Mergenthaler, E. (1996). Emotion-abstraction patterns in verbatim protocols: A new way of describing psychotherapeutic processes. Journal of Consulting and Clinical Psychology, 64(6), 1306-1315. doi: 10.1037/0022-006X.64.6.1306

Páramo, M. D. L. A. (2011). Psicoterapia para adolescentes y perfil del psicólogo: Análisis de contenido de discursos grupales [Adolescent psychotherapy and psychologist profile: Content analysis of group discourses]. Revista Argentina de Clínica Psicológica, 20(2), 133-142.

Reyes, L., Aristegui, R., Krause, M., Strasser, K., Tomicic, A., Valdés, N., ... Echávarri, O. (2008). Language and therapeutic change: A speech acts analysis. Psychotherapy Research, 18(3), 355-362. doi: 10.1080/10503300701576360

Safran, J. D., \& Muran, J. C. (2000). Resolving therapeutic alliance ruptures: Diversity and integration. Journal of Clinical Psychology, 56(2), 233-243. doi: 10.1002/(SICI)1097-
4679(200002)56:2\%3C233::AID-JCLP9\%3E3.0.CO;2-3

Santibáñez, P. (2001). La alianza terapéutica en psicoterapia: traducción, adaptación y examen inicial de las propiedades psicométricas del Working Alliance Inventory en Chile [The therapeutic alliance in psychotherapy: translation, adaptation and initial examination of the psychometric properties of the Working Alliance Inventory in Chile]. Santiago de Chile: Universidad Pontificia Católica.

Searle, J. R. (1969). How to derive 'ought'from 'is'. In W. D. Hudson (Ed.), The is-ought question. Controversies in philosophy (pp. 120-134). London: Palgrave Macmillan.

Shirk, S. R., \& Karver, M. (2003). Prediction of treatment outcome from relationship variables in child and adolescent therapy: a meta-analytic review. Journal of Consulting and Clinical Psychology, 71(3), 452-464. doi: 10.1037/0022006X.71.3.452

Valdés, N., Krause, M., \& Álamo, N. (2011). ¿Qué dicen y cómo lo dicen?: análisis de la comunicación verbal de pacientes y terapeutas en episodios de cambio [What do they say and how do they say it: analysis of verbal communication of patients and therapists in episodes of change]. Revista Argentina de Clínica Psicológica, 20(1), 15-28.

Valdés, N., Tomicic, A., Pérez, J. C., \& Krause, M. (2010). Sistema de Codificación de la Actividad Terapéutica (SCAT1.0): Dimensiones y categorías de las acciones comunicacionales de pacientes y psicoterapeutas [Therapeutic Activity Coding System (SCAT-1.0): Dimensions and categories of communicational actions of patients and psychotherapists]. Revista Argentina de Clínica Psicológica, 19(2), 117-129.

Watzke, B., Koch, U., \& Schulz, H. (2006). Zur theoretischen und empirischen Unterschiedlichkeit von therapeutischen Interventionen, Inhalten und Stilen in psychoanalytisch und verhaltenstherapeutisch begründeten Psychotherapien [On the theoretical and empirical differences of therapeutic interventions, contents, and styles between cognitive behavioural and psychodynamic psychotherapies]. PPmP-Psychotherapie. Psychosomatik Medizinische Psychologie, 56(06), 234-248. 